\title{
Calisthenics Activity as Urban Society Culture of Lampung, Indonesia: in Terms of Expectations, Appreciation, and Public Perception of Calisthenics Activity in Street Workout Lampung Community
}

\author{
Hari Hanggoro*; Agus Kristiyanto; Muchsin Doewes \\ Department of Sport Science, Sebelas Maret University, Indonesi \\ Email: harihanggoro123@gmail.com
}

\begin{abstract}
The development of the times make the public aware that maintaining health is important but this is not supported by the availability of time because it runs out for other activities, and the presence of calisthenics makes the public feel easy to exercise anywhere and anytime, this study aims to see where the concept of calisthenics sport growing in the public and see the supporting aspects so that this sport can grow and be liked by many people. The results obtained in terms of public expectations such as wanting a fit body, healthy, long life, want to be popular, have a complete training program, provide great motivation ,public space provision in the countryside, and from the appreciation marked by the participation of the community is the availability of calisthenics facilities, public space provision, sponsorship support, the ease of licensing, access to information, provide educational space, the freedom of use of facilities, and the preservation of facilities, public perceptions are also very positive in describing calisthenics, the role of government, the concept of exercise, the concept of community and public can describe how to maintain a healthy lifestyle with calisthenics and the conclusions are the development of calisthenics in Lampung province creates a good perspective for the public. This is reflected in the high expectations, appreciation and public perception to street workout community, the public also knows aspects of exercise in this community, and exercise routines are always awake, also the support of government and stakeholders through the provision of a new public space is also getting better, and with the discretion given by the government, health services can provide services in sports centers with a very professional, and also in the provision of public education space, make experts in sports, health, nutrition, psychology can be assembled and share information to the public.
\end{abstract}

Keywords: Appreciation; Calisthenics; Expectation; Perception; Street Workout

\section{Introduction}

Sports and health are the rights and needs of all citizens, although sports and health are not the only way in which the public gets happiness, but with a healthy body and sport, the public is able to fulfill 
the real meaning of life, one of them through physical activity that has become a reference for various countries and institutions that continue to encourage people to actively engage in physical activity, in particular through sports activities (Ks., 2013). In accordance with Law of Indonesia Number 3 of 2005 on National Sports System Article 6 states that every citizen has the same right to a) Engage in sports activities; b) Obtain services in sports activities; c) Choose and follow the type of sport that matches his or her talents and interests; d) Obtain direction, support, guidance, coaching, and development in sports; e) Become a sports actor; f) develop the sports industry (DPR-RI., 2005). In addition to sports, health is also an important aspect, conducted by stakeholders, such as health departments, health department is an existing part of the government that protects the public interest in health, the government makes regulations for the public interest and guarantees all services (Mubasysyir., 1999), with combine sports and health one of them by introducing calisthenics, the public variety to improve life healthily also increases, calisthenics can provide the benefits of muscular and aerobic conditioning, in addition to improving psychomotor skills such as balance, agility, and coordination (PHP., 2018). Calisthenics is a weight training method using bodyweight as resistance to achieve desired stimulation (Kavadlo., D \& Kavadlo., 2016). Calsthenics itself is a method of practice that has been applied for centuries and of course is a long history that will be interesting to explore, and now it is more popularly known as street workout as a culture of the young generation who perform calisthenics in public spaces such as city parks or on the streets, and it can be used to gain weight, and for a thin person can do this sport as an alternative to fitness and also for those who want to lose weight can do this exercise (Kavadlo., 2014), it also can be done anywhere and do not have to go to the gym. Exercise calisthenics has achieved a significant increase compared to groups that did not exercise it, the increase in the selected criterion variables such as speed, cardiovascular fitness, coordination, balance, strength, muscle endurance and strength (Srivastava., 2016).

All sports have their respective advantages, the presence of calisthenics is not to negate the needs of other sports, but it becomes a perfect complementary because of calisthenics train many muscles and various movements that are commonly found in a variety of sports activities. In this era of sports not only limited to healthy and fit, psychological interventions are also able to become the basis for a person to practice and follow one of the exercise models in the sport (Suharman, 2005). With a positive public intervention and perspective has a good impact on the concept of sports itself, including in terms of how much expectations, forms of appreciation and perceptions of the public, then from here will arise a great understanding of the importance of calisthenics in Lampung province. The development of calisthenics is also to be able to provide what is expected of the public. On this basis, the public has a very good understanding of the concept of sports in general and the public also better understand the performance and government policy on sports and health in terms of the existing appreciation. Calisthenics sports is also to be able to provide what is expected of the public, expectations of the public are desirable because expectations are an idea of something in the future or the past about a problem we are sometimes worried about, when we are detecting a possibility in terms of pleasure from opposite situations (C George., 2017), and expectancy is the perceived relationship between individuals efforts and performance of the behavior (Ron., 2013). The point of expectation is that the strength of one's tendency to act in a certain way depends on the power of expectation that the action will be followed by a certain outcome and on the appeal of that result for the concerned, the expectation theory emphasizes the realistic and rational (Siagian., 2012), also an emotion that is directed towards environmental-influenced cognition (Lopez., 2009). So it can be said that expectation is an estimate of the individuals that arise because of the relationship between effort and the results to be achieved.

In addition to expectations, public appreciation also has a positive impact on a sports community, where appreciation is an Assessment of something (Tim Penyusun KBBI., 2008). Appreciation comes from the word appreciate, which means the valuation of the price, the valuation of the price is not to lead to the value of the currency but to assess he quality of an object through measurement and guidelines and one's consciousness in understanding the model (Bahari., 2008). The appreciation of this public indirectly supports the government's program of sport, with all that the government has done from all aspects, the 
form of appraisal and the addition of insight from the public to the government make it the basis for the government to improve service and more positive policies in the sport and health. Appreciation is also formed due to public participation, although still finding the factors responsible for low community participation in government, such as non-compliance with group interests, lack of information, weak public institutions, insufficient assistance, lack of technical knowledge (Wahdy., AA., Maksum., IR., Linda., 2017), other than that Public perception is also very important for the community and the public itself, to assess the extent to which public knowledge of the sports community and what concepts are the basis of community to be widely known to the public, perception itself is a complex set of processes through which we obtain and interpret or give meaning to information obtained through the senses (Ling., 2013). The public perception to a good community can be an indication that their understanding of community performance has been good for, but also the lack of government attention to the sports community as well as the provision of facilities can trigger poor public perception to the government own, changes in the role of local government as stipulated in the law demands the role of public service for quality local government to the community (Sholichah., 2017). These three aspects can be used to measure the success of the government in the realm of sport, with the presence of street workout community of Lampung then the government is helped in running programs in the public health now and in the future, street workout itself is an incredibly comprehensive collection of calisthenics concepts, exercises, and programs. In addition to their masterful demonstrations of every exercise (Kavadlo., D \& Kavadlo., 2016). Street workout and calisthenics are a difficult entity to separate, with street workout hence merging all types of sports can be done, generally type calisthenics sport using public space or place that is provided for sports facilities, while keeping the body healthy and fit, street workout community also has the values of art in the model of practice, one of which is the Lampung street workout community, this community has a very well-organized program, cardio and program to raise muscle mass not only provide knowledge for sports but street workout Lampung also educate about the diet that also affects the exercise program taken. Street workout Lampung now has members who are not few in number and always do regular exercises and now the practice has spread across several regencies/cities in the province of Lampung (Saktiyanto., 2015). The street workout community of Lampung is one of the largest communities and with a positive public rating will feel more attractive, it is important to see how far the role of government through the street workout community in the development of sports as a barometer of development success in a region, with expectations, appreciation, and perceptions of all levels of public, the public itself feels the right to exercise and maintain health. Public organizations as well can understand themselves as agents that live in dynamic environments even though environmental factors are important. the presence of private parties in the health services and public accountability that public demands to be part of the new environment (Wahdy., AA., Maksum., IR., Linda., 2017). by researching expectation, appreciation, and public perception, the researcher can know how health service in every public space at center of sport which is used, how far is public space in every regencies/ city, and how government permit for community and public in calisthenics, and with the results obtained through this research, the government and the community can know which indicators need more attention so that will facilitate the achievement of the successful development of sports and public health in the future.

\section{Methodology}

This was a descriptive qualitative study, with a naturalistic approach. This research was conducted in the main public space in ten regency/ cities in Lampung province from August 2017 to December 2017. The population in this study was all public who are in public space and exercise Calisthenics routine, which is selected by purposive sampling with 150 respondents. Instruments used are the items of the interviews that contain questions that use the psychological approach and conducted (indepth interviews). The ethical approval was obtained from street workout community Association and Informed consent or notice on the subject that they are involved in the research. Data analysis techniques 
used are data reduction, data display, verification and affirmation of conclusions. Data obtained from the respondents tested to ensure trustworthiness with credibility test (internal Validity) researchers use (triangulation, the extension of observations, and references with notes and interviews recordings), transferability test, and dependability test (contains an audit of research activities).

\section{Results}

The researchers managed to get data of respondents from ten regencies/ city in Lampung province and all respondents are public who often do sports activities (regular sport and calisthenics). The result of the research shows the positive expectation, appreciation, and perception of the existence of Lampung street workout community since its establishment until now.

\section{Public's Expectation}

1. The public expects the full support of the government, stakeholders and community members of this sport in terms of upgrading facilities in areas where sports and health facilities are not available.

2. Public expect additional facilities in new area because public said there is still a lack of public space in the newly formed cities in Lampung province and for municipalities such as Bandarlampung whose availability is only12\% (Translampung., 2017) and the metro is only 17\% (Lampung Media Online., 2016) of the total area.

3. Increased security at sports centers is necessary.

4. Encouraging related agencies to cooperate with sports communities in Lampung province.

5. With the public knowing this community, it is expected that all sectors such as government, private, sports and health practitioners work together to improve the good atmosphere in educating the public about the importance of sports and health, especially in terms of support and provision of facilities. as well as maintaining the function and aesthetics of calisthenics space so that all parties can use it.

6. The ease of permission in organizing calisthenics sports events as well as financial support.

7. The public also expects improved exercise variation to avoid boredom to keep the public interested and motivated to keep exercising and maintain health every day.

8. The government policy in other public health can work well, with the community introducing calisthenics to the public, this community can be an alternative to exercise and improve public health over time.

9. The public also expects this community to be able to contribute knowledge about the importance of sports and health, especially sports calisthenics in this community, such as how to make moves, how to avoid mistakes, handling injuries during exercise, how to perform freestyle movements, any food which should be eaten and avoided keeping the body healthy and fit.

10. The public also expects that the socialization of this community in introducing calisthenics and street workout communities is further enhanced, in the form of socialization of training techniques, the socialization of the event, as well as socialization through the official account. 
11. The expects to this community can put forward the concept of a wide friendship without any limitations, including differences in age and gender.

12. They hope by joining this community they can get a job by knowing new people, some are hoping to attract the opposite sex with their muscular body, want to have many new friends, want to avoid something distorted, want to add experience, a special exercise to learn a particular movement, looking for fun, satisfaction, and expect the recognition of others, and expects a healthy lifestyle improvement with exercise.

\section{Public's Appreciation}

1. The public's appreciation of the street workout community and that seeing and training with them is very positive, among others,

2. The public is very appreciative because this community can be used as a means to maintain and improve public health, and can be one indication for healthy living.

3. Appreciation also came from the respondents about the concept and culture of the community is very appropriate for Lampung public who often exercise, especially among young people who want a more challenging exercise and happy with new things.

4. Appreciation is also given because of the government also gives the place and freedom of health practitioners to provide services at sports centers,

5. This community also get a lot of attention not only from the government but from the wider community, such as facilities used to use sponsorship funds or community self-help, that is why facilities are available well although the number of each area is still limited,

6. The ease of a got permission.

7. The public also highly appreciates the ease of obtaining information, such as training schedules, training venues, training programs and the community is also able to provide educational space for the public, about sports, health, exercise program, diet program, is supported by the gathering of practitioners in the field of sports, health, trainers, nutrition experts in a region that makes this concept so important to the public,

8. The public really appreciates the efforts of the community and government to maintain the facility so it can still be used until now, it can be an attraction because a sport's concept that is able to recruit many members from different walks of life, ranging from age, sex, occupation, domicile.

9. The public greatly appreciate this community for being able to tell in terms of exercising and maintaining health in a simple way, the public itself has a favorite movement of this community exercise, although they can not and do not usually do it like freestyle movement,

10.Appreciation also for this community because this community has a concept 'just for fun' for the public who join.

11. This community is also able to recruit young children to join the community in order to practice and healthy together, so that young people can reduce or eliminate bad habits that can damage their health, and also try to avoid young people to do negative things that could harm the public, this is supported 
by data of the statistics center of Lampung province based on the crime against life and physically crime which decreased (BPS., 2016).

12.The public appreciates this community from the aspect of membership, they can still take the time to exercise together and even enter a community that has the same concept and thought to live healthily.

13. The public who exercise has a different point of view, such as parents who exercise calisthenics they just want to lead a healthy life and follow calisthenics activity for health therapy, while the youth is more into a muscular body.

14. The public also appreciates the granting of ease in the use of facilities and the provision of public spaces with government support, from field observation the following are public spaces available in Lampung province (Table 1).

Table 1 Public spaces for calisthenics

\begin{tabular}{|c|c|c|}
\hline City/ Regency & Area $\left(\mathrm{m}^{2}\right)$ & Location [Health service $(\sqrt{ })]$ \\
\hline Bandar lampung & 296.00 & $\begin{array}{l}\text { saburai court }(\sqrt{ }) \text {, pahoman court, unila court, PKOR (wayhalim) }(\sqrt{ }) \text {, } \\
\text { refleksi park, dwipangga park }\end{array}$ \\
\hline Metro & 61.79 & $\begin{array}{l}\text { mulyojati park, merdeka park }(\sqrt{ }) \text {, kihajar dewantara park, palm indah } \\
\text { park }\end{array}$ \\
\hline Lampung Tengah & $3,802.68$ & way terusan SP 1, kampung transad, gunung sugih, \\
\hline Lampung Timur & $5,325.03$ & brimob court, pekalongan court, merdeka park \\
\hline Pringsewu & 625.00 & kuncup court, tanjung anom, \\
\hline Lampung Utara & $2,725.87$ & sukung stadium, taman sahabat, komplek islamic center, \\
\hline Pesisir barat & $2,907.23$ & Labuhan jukung beach, walur beach \\
\hline Lampung Barat & $2,142.78$ & liwa botanical garden, \\
\hline Lampung Selatan & 700.32 & $\begin{array}{l}\text { Dermaga BOM }(\sqrt{ }) \text {, Sidomulyo jogging track, sport center kalianda, } \\
\text { korpri, kain inuh park }\end{array}$ \\
\hline Tanggamus & $3,020.64$ & Tangsi court, \\
\hline
\end{tabular}

Source: Primary data \& Dinas Tata Kota

\section{Public's Perception}

1. The government policies for the community in terms of licensing, provision of facilities, and improvement of health services have a positive impact.

2. The street workout community provides a more good direction for other community.

3. The public knows substantially the street workout community, what kind of exercises do every day and know the direction and benefits of this community.

4. The public also thinks that calisthenics exercise has a significant impact on health in general,

5. The public also said that calisthenics is a simple sport but able to be an interesting activity in the community and provide a real sense of the sports concept at no cost.

6. Community supported by the government and managed to make many practitioners in sports and health come to join. 
7. The community that can be an attraction for all people to participate in practicing or sharing knowledge about the concept of sports and health.

8. Communities that are able to build large amounts of public participation.

9. The public also knows the activities that are often done community in the public, in terms of sports and health and other activities, and know what government policies are for the existing sports community, especially the street community of Lampung.

10.A solid community, building a sense of brotherhood, and introducing the public about sports that can be done anywhere.

11.Communities that have a good attitude when using the facilities provided.

12.The Public is also aware that this community receives members from various public layers,

13.Introducing activities that are able to develop creativity in supporting public health, of the number of movements performed, the researchers identified the most frequently performed movements in terms of age and gender (Tabel 2).

Tabel 2 The most used movements and Location (age and gender)

\begin{tabular}{|c|c|c|}
\hline & \multicolumn{2}{|c|}{ Calisthenics Movement } \\
\hline & Male & Female \\
\hline $\begin{array}{l}\text { Age (year) } \\
16-25\end{array}$ & $\begin{array}{l}\text { Jumping jack, squad, muscle up, } \\
\text { human flag, push up combination, planche, lever }\end{array}$ & Lunge, crunches \\
\hline Location & Public space & Home/ public space \\
\hline $26-35$ & $\begin{array}{l}\text { Combine the entire series of motion and perform } \\
\text { freestyle at the end of the repetition }\end{array}$ & $\begin{array}{l}\text { Lunge, crunches, push } \\
\text { up, streetching }\end{array}$ \\
\hline location & Public space, beach & Public space \\
\hline $36-60>$ & $\begin{array}{l}\text { Frog stand, human flag, Korean dips, push up } \\
\text { variation (one hand push up, archer pushup, } \\
\text { handstand push up, typewriter pushup, clap pushup, } \\
\text { double clap pushup, combinations pushup) }\end{array}$ & $\begin{array}{l}\text { Burpee, leg raises, leg } \\
\text { bench dips }\end{array}$ \\
\hline Location & Public space, home & Public space/home \\
\hline $70>$ & $\begin{array}{l}\text { Inverted rows, static pull up, static chin up, } \\
\text { Lunge, crunches }\end{array}$ & Jogging and streetching \\
\hline Location & Public space, home & home \\
\hline
\end{tabular}

\section{Conclusion}

This study is the first study conducted in Lampung province in the field of calisthenics, this research was conducted with the aim to know the extent to which the development of public health concepts in terms of calisthenics activity, and to know the extent of government support to the community of Street workout in sports and health, seen from expectations, appreciation, public perception of large community in Lampung province, these aspects specialize in health services in public sports centers, provision of sports facilities and licensing and are expanded with public statements related to community, sports and health in Lampung province in general. 
This research can be an evaluation and indicator for the community and government in all aspects to improve the positive perspective of the public. Based on the research result, the street workout community in Lampung province and governments are highly appreciated by the public both in terms of training, membership, and activities to the public health by holding sport's event, and if seen from the large expectations of the community on this community, where people can take advantage of this community that includes public health and sport, over the times makes the sport that has a simple concept can have a great attraction in the community, with the presence of calisthenics, the public get very great motivation in exercising and also in maintaining the health of his body, with the increasing number of the public that uses calisthenics as the concept of motion, the greater the public's sympathy for the Governments and community, Understanding and finding out what are the views of the public in some aspects, are endeavored to help develop and support this growing calisthenics in order to become a large community and supported by all parties, especially for public health, this community also Able to keep the public especially young people to avoid negative activities, and can also be a place of gathering and sharing for fellow members and the surrounding public in terms of increasing sport and health knowledge, especially in the field of calisthenics, and public also expects full government support from all aspects of sports facilities, public space provision, licensing, the need for a thorough socialization of the community, good facilities, increased training variations, improved healthcare policies, enhanced practitioners in handling injuries, fun community, and public appreciation of this community with the full support of the government is very good, from how they appreciate the available calisthenics facilities, and wherever the public space is often done for sports activities, how its health services in sports centers, licensing and funding assistance issued to build public space, freedom of use of existing facilities, and make all can exercise safely, and comfortable, and positive perceptions of the public's knowledge of this community are also very well seen from the people who are able to explain about the community of street workout although still simple but understood substantially. And also from the many people who know because often practice and just look from a distance, the public is also able to explain the form of community socialization that explains what activities are obtained directly or from official account, and also the public is able to explain the exercises, characteristics, and existence of communities that contribute positively to public. and be able to explain what the government's contribution to sports and health such as the provision of public space and anywhere where it is provided, and in the case of public health services can also consult and check-up, and for the public, the public are able to explain simply when space public can be used with ease to any activity in accordance with its regulations. The provision of adequate Bar and grounding facilities is necessary to increase the good interest in health and sports. For the public that participates in sports activities to maintain health especially in calisthenics and participates in maintaining the facilities already provided by the government, to the public to help each other and maintain security in all public space in order to create a conducive situation and conditions during the exercise.

The policies of the Lampung provincial government that are good in public health and the provision of facilities can be seen in some places of calisthenics facilities in sports centers, although there are only a few places that are lacking. With that aspect, the sports that are present in the public have meaningful value, the concept of urban sport that is easily accepted and followed, in the future can give a greater impact to the public, to the sports experts, to the physical trainer, to be together to contribute for calisthenics in big cities, with the gathering of sports practitioners, trainers, nutritionists, medical scholars, former athletes in one unity makes public perspective better for health and sport, making a city whose public has good access to information for healthy living, know how to exercise properly and the disadvantages of what should be abandoned, become all dreams, both government, community, stakeholders, and the public itself. and in the future, making Lampung province even better in sport and health in public including facilities and services and the results of this study can also be applied to other areas as a basis for developing public health concepts based on the perspective, needs of public and government support to a sports community. 


\section{Acknowledge}

Thanks to Professor Agus Kristiyanto and Professor Muchsin Doewes for guidance and advice, and to friends who have assisted in the research, as well as to all the respondents who took the time to be interviewed.

\section{References}

Bahari, N. (2008). Kritik Seni: wacana apresiasi dan wacana. Yogyakarta: Pustaka Pelajar.

BPS. (2016). Statistk Keamanan Provinsi Lampung. Lampung.

C George, B. (2017). Personality Theories. Createspace Independent Publishing Platform.

DPR-RI. (2005). Undang-undang Republik Indonesia. Jakarta.

Kavadlo, D \& Kavadlo, A. (2016). Street Workout, A Worldwide Anthology of Urban Calisthenics. United State: Dragon Door Publication, inc.

Kavadlo, A. (2014). Stretching Your Boundaries: Flexibility Training for Extreme Calisthenic Strength. United State: Dragon Door Publication, inc.

Ks, S. (2013). Keikutsertaan Masyarakat dalam Kegiatan Olahraga. Jurnal Media Ilmu Keolahragaan Indonesia.

Lampung Media Online. (2016). RTH Kota Metro Hanya 17 Persen. Metro: Lampung Media online.com. Retrieved from http://lampungmediaonline.com/2016/10/rth-kota-metro-hanya-17-persen/.

Ling, J. \& J. C. (2013). Psikologi Kognitif. Jakarta: Erlangga.

Lopez, S. J. (2009). The Encyclopedia of positive Psychology. hhtps://doi.org/10.1002/9781444306002.

Mubasysyir, H. (1999). Memperkokoh Posisi Departemen Kesehatan Dalam Sektor Kesehatan Publik. Jurnal Kebijakan \& Administrasi Publik 3(1): 73-82.

PHP. (2018). Wikipedia. Wikipedia, Ensiklopedia Bebas. Diakses pada 5:27, Maret 5, 2018. Retrieved from https://en.wikipedia.org/w/index.php?title=Calisthenics\&oldid=827391872.

Ron, R. (2013). Introduction to Industrial and Organizational Psychology. (J. Mosher, Ed.) (Sixth). United State: Pearson Education inc.

Saktiyanto, A. (2015, Desember 2). Street Workout Lampung Komunitas Olahraga Tanpa Nge-Gym. Bandar Lampung: Saibumi.com. Retrieved from http://www.saibumi.com/artikel-70618-street-workoutlampung-komunitas-olahraga-tanpa-ngegym.html.

Sholichah, N. (2017). Apresiasi Masyarakat Miskin Terhadap Layanan Sosial Dasar Pemerintah. Jurnal Komunikasi Profesional 1(1):1-21.

Siagian, S. P. (2012). Teori Motivasi dan Aplikasinya. Jakarta: PT Rineka cipta. 
Srivastava, R. (2016). Effect of Pilates, Calisthenics and Combined Exercises on Selected Physical Motor Fitness. New Delhi: Isara Publications.

Suharman. (2005). Psikologi Kognitif (edisi revi). Surabaya: Srikandi.

Tim Penyusun KBBI. (2008). Kamus Besar Bahasa Indonesia. Jakarta: Pusat Bahasa.

Translampung. (2017, 15 Maret). Ruang Terbuka Hijau Baru 12 Persen. Lampung: Translapung.com. Retrieved from http://translampung.com/ruang-terbuka-hijau-baru-12-persen/.

Wahdy, AA., Maksum, IR., Linda, D. (2017). The Challenges of Enhancing Participation in Urban Community Empower-ment. Jurnal Kebijakan \& Administrasi Publik, 21(2): 107-125.

\section{Copyrights}

Copyright for this article is retained by the author(s), with first publication rights granted to the journal.

This is an open-access article distributed under the terms and conditions of the Creative Commons Attribution license (http://creativecommons.org/licenses/by/4.0/). 